\title{
Different Imazethapyr Placements and Rainfall Amounts Affect Phytotoxic Activity of Imazethapyr in Combination with Oil Palm Frond Residue Mulches against Common Weeds in Landscapes
}

(Penempatan Imazetapir dan Kuantiti Hujan Mempengaruhi Aktiviti Kefitotoksikan Gabungan Imazetapir dengan Sungkupan Pelepah Kelapa Sawit terhadap Kawalan Rumpai dalam Landskap)

\author{
Muhammad Amirul Nordin, DilipKumar Masilamany \& ChUAH Tse SENG*
}

\begin{abstract}
A combination of oil palm frond (OPF) mulch and imazathapyr has been shown to provide great inhibition of weed but its phytotoxicity may be influenced by imazethapyr placement on the OPF mulch and rainfall amount. This study aimed to evaluate effects of herbicide placement and rainfall amount on the phytotoxic activity of imazethapyr in combination with OPF mulches against goosegrass, slender cyperus and coat buttons under glasshouse conditions. Imazethapyr was applied at $10.4 \mathrm{~g}$ a.i. ha $\mathrm{a}^{-1}$ to under or above or as a pretreatment on the OPF mulch residue powder $(<2 \mathrm{~mm})$ at $3.5 \mathrm{t}$ $\mathrm{ha}^{-1}$. Imazethapyr placement did not influence its inhibitory effects against weed emergence. Both pretreated mulches and imazethapyr applied under the mulches had comparable inhibition of seedling growth for goosegrass and slender cyperus. However, the pretreated mulches gave better seedling growth inhibition of both bioassay species as compared to those of imazethapyr that applied above mulches. Coat button was highly inhibited regardless of any imazethapyr placements. An increase in rainfall amount from 150 to $450 \mathrm{~mm}$ could increase the seedling emergence of goosegrass and slender cyperus from 30 to $80 \%$ when subjected to pretreated mulches. However, different rainfall amounts had no significant effect on coat buttons seedling emergence. The pretreated mulches could reduce weed seedling growth by 75 to $80 \%$ without being affected by the rainfall amounts. The present results suggested that phytotoxic activity of imazethapyr in combination with OPF residue mulches is dependent on imazethapyr placement, rainfall amount and weed species.
\end{abstract}

Keywords: Herbicide placement; imazethapyr; oil palm frond mulch; rainfall amount

ABSTRAK

Kombinasi antara sungkupan pelepah kelapa sawit (PKS) dan imazetapir telah menunjukkan perencatan rumpai yang baik tetapi kefitotoksikannya mungkin dipengaruhi oleh penempatan imazetapir pada PKS dan kuantiti hujan. Kajian ini bertujuan untuk menilai kesan penempatan racun rumpai dan kuantiti hujan terhadap aktivit kefitotoksikan kombinasi imazetapir dengan sungkupan PKS terhadap rumput sambau, rumput wangi dan kancing baju di bawah keadaan rumah kaca. Imazetapir pada $10.4 \mathrm{~g}$ a.i. ha ${ }^{-1}$ ditempatkan sama ada di bawah atau di atas atau sebagai

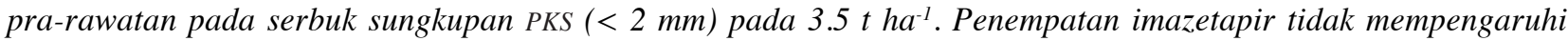
keberkesanannya terhadap perencatan kemunculan rumpai. Pra-rawatan sungkupan dan imazetapir yang disembur di bawah sungkupan mempunyai perencatan yang setanding terhadap pertumbuhan anak benih rumput sambau dan rumput wangi. Walau bagaimanapun, pra-rawatan sungkupan memberi perencatan yang lebik baik terhadap pertumbuhan kedua-dua spesies bioasai berbanding dengan yang disembur di atas sungkupan. Kancing baju mempunyai perencatan yang tinggi tanpa mengira sebarang penempatan imazetapir. Peningkatan kuantiti hujan daripada 150 hingga $450 \mathrm{~mm}$ dapat meningkatkan kemunculan anak benih rumput sambau dan rumput wangi daripada 30 hingga $80 \%$ apabila diperlakukan dengan pra-rawatan sungkupan. Walau bagaimanapun, kuantiti hujan yang berbeza tidak memberi kesan yang bererti pada kemunculan anak benih kancing baju. Pra-rawatan sungkupan dapat mengurangkan pertumbuhan benih rumpai sebanyak 75 hingga 80\% tanpa dipengaruhi oleh kuantiti hujan. Keputusan kajian ini mencadangkan bahawa aktiviti kefitotoksikan imazetapir yang dicampur bersama sungkupan PKS adalah bergantung kepada penempatan imazetapir, kuantiti hujan dan spesies rumpai.

Kata kunci: Imazetapir; kuantiti hujan; penempatan racun rumpai; sungkupan pelepah kelapa sawit

\section{INTRODUCTION}

Weeds in the landscape and nursery industry are currently controlled by physical, cultural, or and/or chemical methods. Weed control in container nursery production is mainly achieved by the use of herbicides and handweeding. Mulching and cultivation are also sometimes employed to control weeds in field nursery production (Appleton \& French 2000). At the present time, herbicides 
are the most widely used and effective tools for weed management in the commercial landscape and nursery industry (Somireddy 2012).

Imazethapyr [5-ethyl-2-(4-isopropyl-4-methyl-5-oxo2-imidazolin-2-yl)nicotinic acid] belongs to a class of chemicals known as imidazolinones is used as a selective herbicide for the control of a broad spectrum of broadleaf and grassy weeds (Thomson 1993). Currently, in Malaysia imazethapyr has been applied either pre- or post-emergence herbicides in oil palm (Ainie et al. 2007), rubber (Faiz 1999) and coconut plantation (Dilipkumar et al. 2017). However, there has been limited research on the usage of imazethapyr in landscape industry. According to Vencill (2002), imazethapyr generally absorbs rapidly into foliage which inteference occur in DNA synthesis and cell growth due to the inhibition of acetolactate synthase (ALS) and injury symptoms usually appear after 1 to 2 weeks or more. Meristematic areas become chlorotic, followed by a slow general foliar chlorosis and necrosis results from events occurring in response to ALS inhibition. Persistence of imazethapyr is moderate with a 60 to 90 -day field half-life.

Organic mulches have even been shown to reduce emergence and establishment of some of the most troublesome weeds (Marble 2015). Benefits from organic mulches are well established and a wide variety of mulch products are available for landscape use (Chalker-Scott 2007). In landscape studies conducted on tree-derived mulches, weed control was deemed acceptable and greater than non-treated control plots (Broschat 2007). The present study used oil palm fronds (OPF) as organic mulch because the availability OPF supply throughout the year in oil palm cultivation (Khalid et al. 1999). In addition, Chuah and Lim (2015) found that the rachis extract of OPF mulch provided complete inhibition of goosegrass germination at a concentration of as low as $1.0 \%(\mathrm{w} / \mathrm{v})$.

Use of preemergence herbicides in combination with mulch is an inexpensive method to provide a broader spectrum, longer lasting weed control (Chen et al. 2013). In addition, applying selective pre emergence herbicides in combination with mulching may improve control efficacy and reduce the need for subsequent post emergence applications (Chen et al. 2013). For example, $O P F$ at $3.4 \mathrm{t} \mathrm{ha}^{-1}$ treated with imazethapyr at $24 \mathrm{~g}$ a.i. ha ${ }^{-1}$ have demonstrated excellent control of Mikania micrantha, Asystasia gangetica, Phyllanthus amarus, Panicum sp. and Echinochloa colona by reducing their total dry weight up to $95 \%$ at three months after treatment in the field (Dilipkumar et al. 2017). Improved herbicide efficacy was reported from studies where herbicides were sprayed to above, under or a pretreatment on the organic mulch over nursery containers (Chen et al. 2013; Somireddy 2012). However, there are no 'herbicide placement' recommendations on pre-emergence herbicide labels in terms of above or under mulch layers (Marble 2015).

Rainfall occurring after the pre-emergence application of herbicides may compromise weed control. Leaching ability is affected by amount of irrigation or rainfall immediately after herbicide treatment (Jursik et al. 2013).
Smith et al. (2016) stated that it is important to understand which irrigation rates are most appropriate for herbicide incorporation to optimize weed management programs. The amount and intensity of the rainfall can influence the rate of absorption and translocation of the herbicides, as well as the efficiency of the weed control (Martini et al. 2003; Monquero \& Silva 2007). This study aimed to evaluate effects of imazethapyr placement on its phytotoxic activity against selected weeds and to determine whether the phytotoxicity of imazethapyr in combination with OPF mulches could be influenced by rainfall amount.

\section{MATERIALS AND METHODS}

\section{EXPERIMENTAL SITE}

Glasshouse experiments were conducted at the School of Food Science and Technology, Universiti Malaysia Terengganu, Terengganu, Malaysia $\left(5.24^{\circ} \mathrm{N}, 103.05^{\circ} \mathrm{E}\right)$ with temperature and light intensity ranging from $29-32^{\circ} \mathrm{C}$ and $800-1200 \mu \mathrm{Em}^{-2} \mathrm{~s}^{-1}$, respectively.

\section{HERBICIDES AND PLANT MATERIALS}

Analytical standard grade of imazethapyr (99.9\% purity) (Table 1) was purchased from PESTANAL $\AA$, SigmaAldrich. Seeds of three common weed species found in landscapes including goosegrass (Eleusine indica), slender cyperus (Cyperus distans) and coat buttons (Tridax procumbens) which represent grassy weed, sedge and broadleaf weed, respectively, were collected from Bukit Kor, Terengganu, Malaysia ( $\left.5^{\circ} 22^{\prime} \mathrm{N}, 103^{\circ} 18^{\prime} \mathrm{E}\right)$. Eleusine indica seeds were scarified with sand papers. Seeds of each bioassay species were soaked in $0.2 \%$ potassium nitrate solution for $24 \mathrm{~h}$ to break dormancy before being used. A preliminary viability test was conducted and confirmed that germination rate of the seeds had more than $90 \%$. Fresh oil palm (Elaesis guneensis var. Tanera) fronds were collected from Mardi Seberang Prai Pulau Pinang, Malaysia ( $\left.5^{\circ} 54^{\prime} \mathrm{N}, 100^{\circ} 47^{\prime} \mathrm{E}\right)$. The fronds were harvested from 35 -years old oil palm trees; they were cut into small pieces with 6-10 cm length using a chopper machine (DISK MILL FFC-23, Shandong JimoHairong Machinery Co. LTD) and dried under direct sunlight at the glasshouse for one month. After completely dried, the fronds (OPF) residue powders $(<2 \mathrm{~mm})$ were stored in a chiller $\left(4^{\circ} \mathrm{C}\right)$ prior to use.

\section{IMAZETHAPYR PLACEMENT TEST}

A total of $150 \mathrm{~g}$ ( $44 \%$ clay, $10 \%$ silt and $46 \%$ sand, $\mathrm{pH} 4.3$, $1.7 \%$ organic matter, $0.5 \%$ nitrogen, $1.7 \mathrm{mg} / \mathrm{kg}$ phosphorus, $102.1 \mathrm{mg} / \mathrm{kg}$ potassium $\mathrm{mg} / \mathrm{kg}$ and $2.2 \mathrm{meq} / 100 \mathrm{~g} \mathrm{CEC}$ ) sandy clay soil was mixed with $0.22 \mathrm{~g}$ chicken dung and filled in a paper cup ( $7 \mathrm{~cm}$ diameters $\times 9 \mathrm{~cm}$ height) with 6 holes at the bottom. Then, the cup was placed in a 50 $\times 100 \mathrm{~cm}$ tray and water was applied from the bottom of the cup until moist condition was achieved, rephrased as paper 1. Ten seeds of goosegrass were sown onto soil surface for each cup under glasshouse conditions. The 
TABLE 1. Physico-chemical properties of imazethapyr

\begin{tabular}{ll}
\hline Chemical structure & 289.33 \\
& Imidazolinone \\
Molecular weight & 1400 at $\mathrm{pH} 7$ and $25^{\circ} \mathrm{C}$ \\
Chemical family & $97-283$ \\
Water solubility $(\mathrm{mg} / \mathrm{L})$ & Weak acid \\
Koc (mL/g) & Inhibits acetolactate synthase (ALS) \\
Ionic property & \\
Mode of action &
\end{tabular}

Gillespie et al. 2011 and Vencill 2002

same procedure was repeated for slender cyperus and coat buttons. A previous study has proven that imazethapyr is compatible with OPF residue when applied in combination for weed control. The rates of imazethapyr and OPF mulch examined in the present study are derived from the findings of Dilipkumar et al. (2017). Imazethapyr was applied at $10.4 \mathrm{~g}$ a.i. ha ${ }^{-1}$ to under or above or as a pretreatment on the OPF mulch residue powder at $3.5 \mathrm{t} \mathrm{ha}^{-1}$. Imazethapyr was dissolved in acetone and pipetted into $9 \mathrm{~cm}$ diameter Petri dish containing of $1.56 \mathrm{~g}$ sieved soil $(2 \mathrm{~mm})$ or $1.56 \mathrm{~g}$ OPF residue powders at room temperature. An additional 4 and $8 \mathrm{~mL}$ acetone were poured into the soil or OPF residue powders, to create more uniform of distribution of the herbicide. Each Petri dish was sealed and gently shaken to allow thorough incorporation of the solution into the soil or OPF residue powders, placed in a fume hood for $24 \mathrm{~h}$. One day after seed sowing, the imazethapyr-treated OPF was placed at soil surface of paper cups. For under mulch placement, the imazethapyr-treated soil was placed at the soil surface of paper cups, followed by the application of $1.56 \mathrm{~g}$ OPF mulch. For above mulch placement, 1.56 $\mathrm{g}$ OPF were placed on bare soil in paper cups, followed by the application of imazethapyr that dissolved with acetone on the OPF mulch surface using a micropipette. The untreated bare soil was served as control. Then, each cup was irrigated with $10 \mathrm{~mL}$ of water from the top of the cup daily to ensure seed germination. Three weeks after treatment, the number of seedling emergence was counted and above ground plant tissues were harvested and oven-dried at $60^{\circ} \mathrm{C}$ for 2 weeks to obtain shoot biomass. Seedlings were considered emerged when the plumule lengths were $>2 \mathrm{~mm}$. The data were expressed as percentages of their respective controls. The experiment was arranged as complete randomized design with three replicates and repeated twice.

\section{RAINFALL AMOUNT TEST}

Imazethapyr was applied at $10.4 \mathrm{~g}$ a.i. $\mathrm{ha}^{-1}$ as a pretreatment on the OPF residue mulches at $3.5 \mathrm{t}$ ha- 1 as described previously. One day after seed sowing, the pretreated OPF mulch was placed at the soil surface of each paper cup containing $150 \mathrm{~g}$ soil and irrigated with 7, 14 and $21 \mathrm{~mL}$ of water, respectively, each day to simulate respective 150 , 300 and $450 \mathrm{~mm}$ rainfall amount. The untreated bare soil was served as control. Three weeks after treatment, the number of seedling emergence was counted and above ground plant tissues were harvested and oven-dried to obtain shoot biomass. The data were expressed as percentages of their respective controls. The experiment was arranged as complete randomized design with three replicates and repeated twice.

\section{STATISTICAL ANALYSIS}

The percentage data of weed emergence and shoot biomass were checked for homogeneity of variance before being subjected to one-way analysis of variance (ANOVA). Since the time factor was not significantly different, data were pooled and combined. Square root transformation was performed on the data of slender cyperus seedling biomass in herbicide placement test before being subjected to ANOVA. Means were compared using the Tukey test at 5\% of significant level.

\section{RESULTS AND DISCUSSION}

Imazethapyr was selected as potential pre emergence herbicide and examined on three selected weed species commonly found in landscapes because its synergistic combination effect with OPF residue mulch has been proven in our previous study (Dilipkumar et al. 2017). In general, there were significant difference in inhibition of weeds except for coat buttons when subjected to different imazethapyr placements (Figure 1) and rainfall amounts (Figure 2).

\section{PHYTOXICITY OF DIFFERENT IMAZETHAPYR PLACEMENTS ON OIL PALM FROND RESIDUE MULCH AGAINST WEEDS}

Figure 1 depicts herbicidal activity of different imazethapyr placements on oil palm frond (OPF) residue mulch on goosegrass, slender cyperus and coat buttons three weeks after treatment. Imazethapyr placement had no significant 
effect on the herbicide efficacy for inhibition of weed emergence. Imazethapyr in combination with the OPF mulch gave 50 to $70 \%$ inhibition of the weed seedling emergence even with the thickness of mulch at as low as $0.5 \mathrm{~cm}$. Similarly, Samtani et al. (2007) reported that diuron or oryzalin-treated leaf pellets, rice hulls, and pine bark applied at a thickness of $0.5 \mathrm{~cm}$ effectively reduced weed biomass in containers for up to 120 day after treatment (DAT). Some of the researchers have achieved weed control with dichlobenil combination with milled pine bark mulch applied at a thickness of as low as $1 \mathrm{~cm}$ (Thomas 1973).

The pretreated OPF mulch gave greater inhibition $(85 \%)$ of slender cyperus and goosegrass seedling growth as compared to imazethapyr applied above mulch (75\%). However, imazethapyr applied to under or as a pretreatment on the OPF mulch provided comparable inhibition (80-90\%) on seedling growth of both bioassay species. Somireddy (2012) examined efficacy of a liquid formulation consisting of trifluralin + isoxaben $(\mathrm{T}+\mathrm{G})$ which was applied at 4.48 $\mathrm{kg}$ ai $/ \mathrm{ha}+1.12 \mathrm{~kg}$ ai $/$ ha directly to soil, above mulch, under the mulch or as pretreated mulch. It was found that $\mathrm{T}+\mathrm{G}$ under $3 \mathrm{~cm}$ pine nugget mulch had similar result of inhibiting weed growth with $\mathrm{T}+\mathrm{G}$ treated $3 \mathrm{~cm}$ pine nugget mulch and the pretreated much inhibited the weed growth better than $\mathrm{T}+\mathrm{G}$ above $3 \mathrm{~cm}$ pine nugget mulch. However, seedling growth of coat buttons was inhibited by $75 \%$ regardless of imazethapyr placement on OPF mulch in the present study.

Imazethapyr applied under mulch resulted in better control than applying above for slender cyperus. Likewise, yellow nutsedge shoot density was generally lesser when EPTC was applied under mulch compared with above-mulch applications (Chen et al. 2013). Several hypotheses have been proposed to explain greater efficacy of herbicide when applied under mulch (Chen et al. 2013; Lanphear 1968). Since the volatilization of imazethapyr in soil is negligible (Anderson 2006), the loss of imazethapyr efficacy applied above mulch is unlikely due to the herbicide volatilization. It is possible that lower light intensity under mulches may have reduced degradation rate as compared with that applying above mulches because imazethapyr is susceptible to photodegradation (Curran et al. 1992). Alternatively, it is likely that herbicides applied directly to soil provided high inhibition of weed emergence, and the mulch then prevented establishment of weeds (Somireddy 2012).

Several studies have shown increased weed control with different herbicides when impregnated or incorporated into mulch than when the herbicide or mulch is used alone (Mathers 2003; Samtani et al. 2007). Case and Mathers (2006) reported higher weed control efficacy 115 DAT with herbicide-treated mulches such as flumioxazin-treated hardwood, oryzalin-treated pine nuggets and flumioxazintreated rice hulls in containers. Same authors documented that the application of the herbicide-treated bark nuggets resulted in increased and extended herbicide efficacy compared to the herbicides or mulches applied alone. Our results are in agreement with these previous studies where the pretreated OPF mulches provided great inhibition of weed growth may be due to the occurrence of synergistic activity between imazethapyr and allelochemicals released from the OPF mulches.

It is critical to examine different herbicide placement because it affects weed germination through various mulch-herbicide combinations and provide significant knowledge in this area concerning weed control efficacy. The findings of present study have shown that the best placement of imazethapyr when combined with OPF mulch for weed inhibition in container nursery. Although both pretreated mulch and imazethapyr applied under the mulches had comparable phytotoxcity on weed seedling growth, the pretreated mulch was selected for subsequent experiment to determine whether the phyototoxic activity of pretreated mulch could be affected by the rainfall amount. The pretreated mulch was chosen because it could save labour cost where it involves only a single application whereas imazethapyr applied under the mulch requires initial application of imazethapyr on soil followed by application of the mulch.

\section{EFFECTS OF DIFFERENT RAINFALL AMOUNTS ON PHYTOXICITY OF IMAZETHAPYR-TREATED OIL PALM FROND RESIDUE MULCH AGAINST WEEDS}

Figure 2 presents influence of different rainfall amounts on inhibitory effect of imazethapyr- treated oil palm residue mulch on goosegrass, slender cyperus and coat buttons three weeks after treatment. Rainfall amount gave significant effect on efficacy of the pretreated mulch in inhibiting weed seedling emergence except for coat buttons. Increasing rainfall amount from 150 to $450 \mathrm{~mm}$ could reduce efficacy of the pretreated mulches by 30 to $40 \%$ on inhibition of weed emergence, with goosegrass being more affected than slender cyperus probably due to the mechanism of imazethapyr which acts as shoot inhibitor rather root inhibitor (Vencill 2002). In addition, high rainfall may have distracted the physical barrier of OPF mulches to prevent the weed emergence. However, coat buttons seedling emergence can be suppressed by 60 to $70 \%$ without being influenced by rainfall amount.

Herbicide-treated mulch effectiveness for weed control depends on rainfall or irrigation as it affects desorption of the herbicide from mulch and soil, which in turn affects efficacy and biodegradation of the herbicides. Interestingly, different rainfall amounts had no significant effect on efficacy of the pretreated mulch for inhibition of weed seedling growth. The pretreated mulch could reduce the weed seedling growth by 75 to $80 \%$, implying that leaching potential of imazethapyr may be negligible even under high rainfall amount of $450 \mathrm{~mm}$. Sondhia (2013) reported that approximately 50\% imazethapyr was found distributed in $0-10 \mathrm{~cm}$ depth in soil column when the herbicide was applied at $200 \mathrm{~g} \mathrm{ha}^{-1}$ in the field with 0 to $130 \mathrm{~mm}$ monthly rainfall within four months of experimental period. It has been documented that 

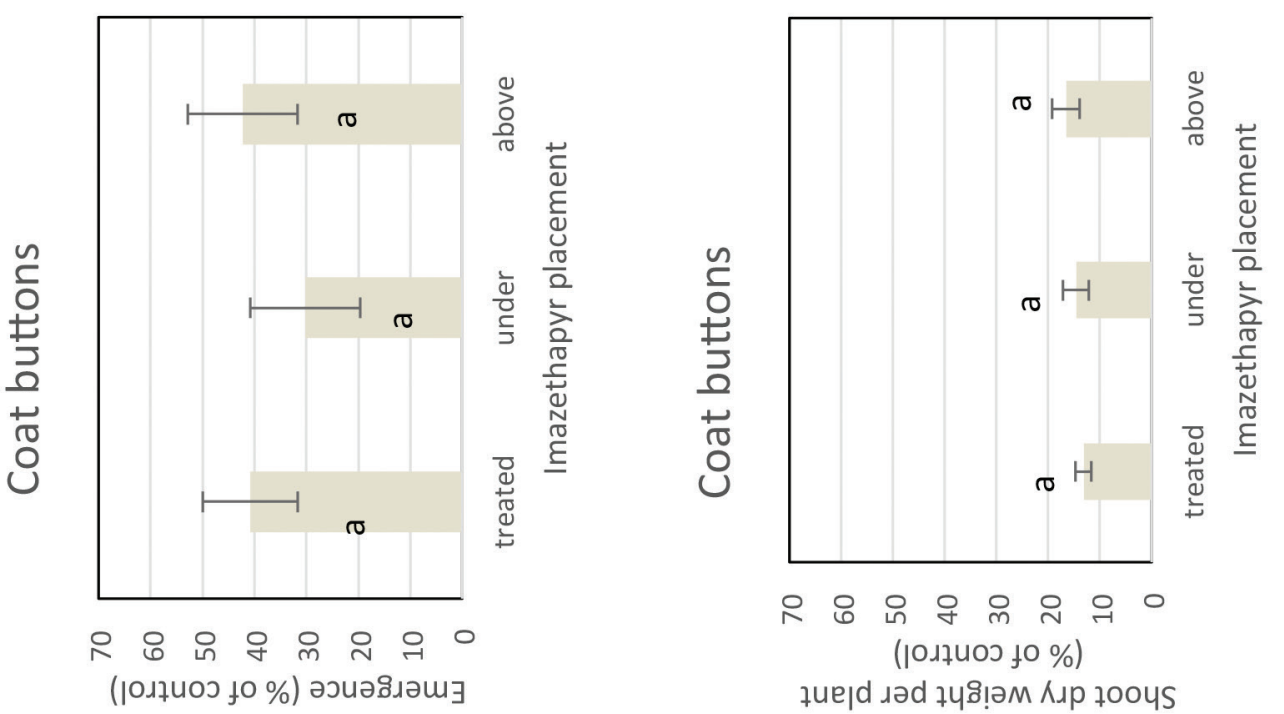

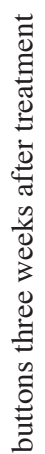
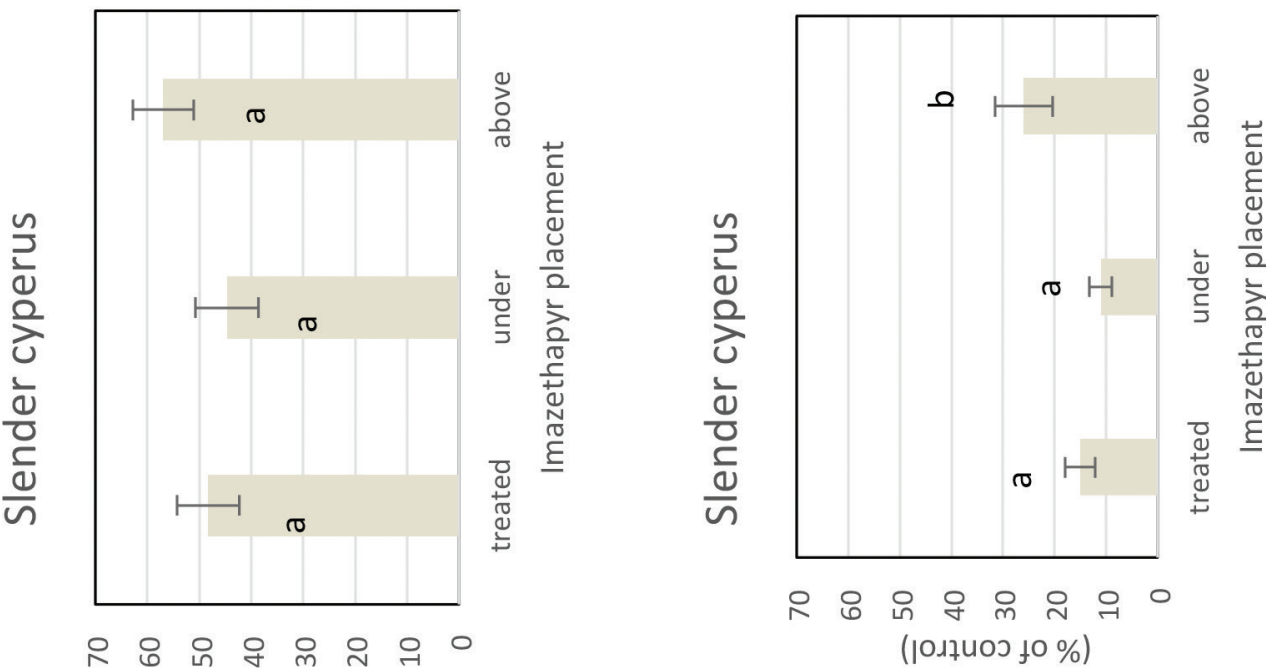

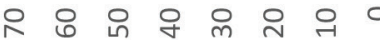

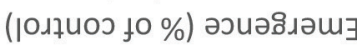

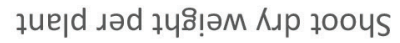
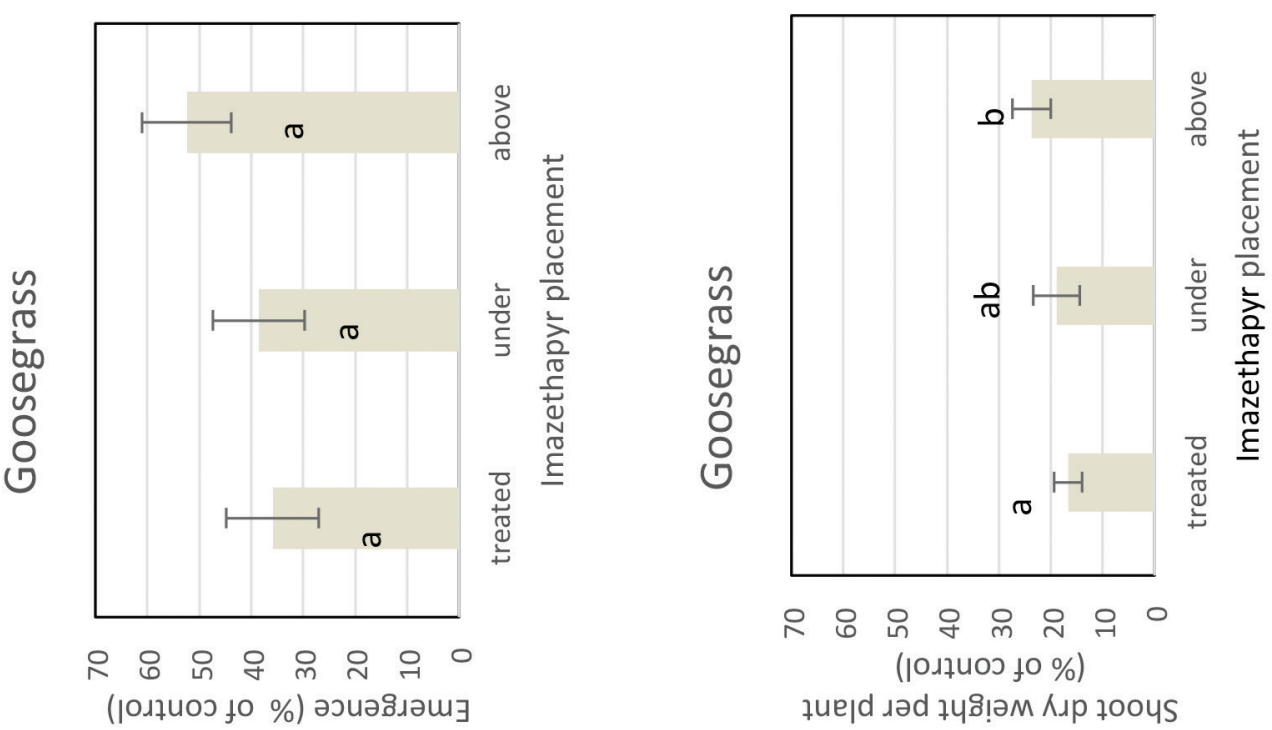


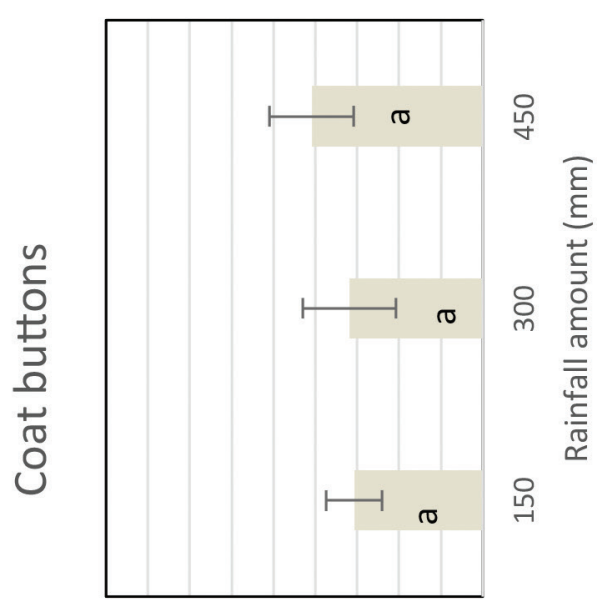

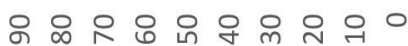

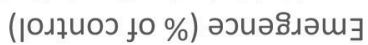

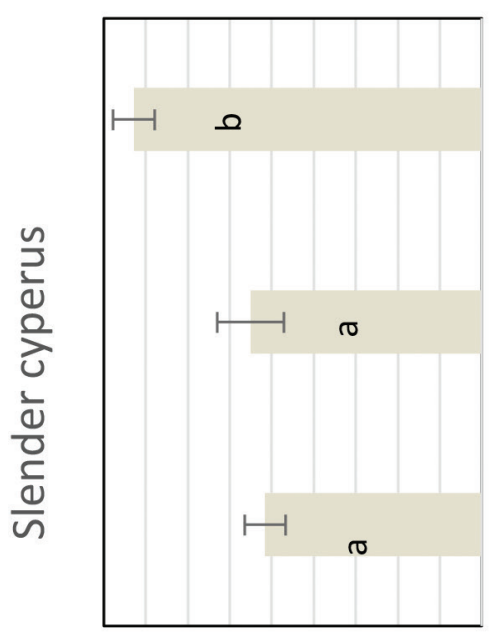

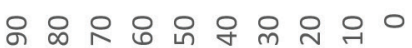

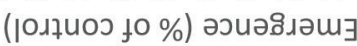

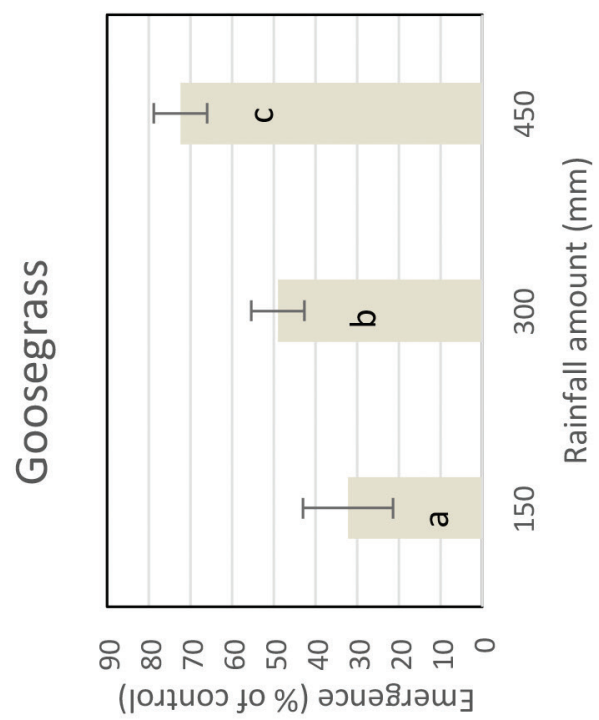

หั่

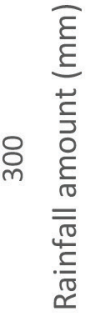

号
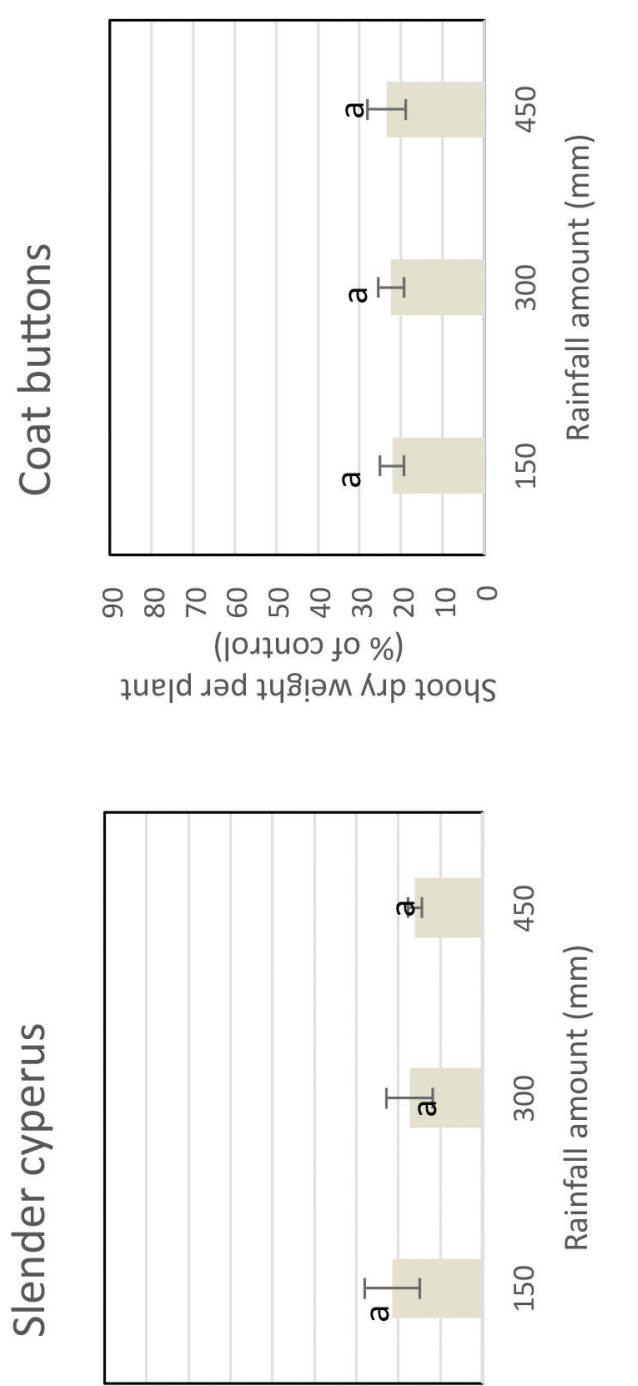

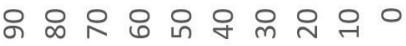
(ן-17u0 f० \%)

ұue|d ıəd ұчร! ам Кıр ұоoчs

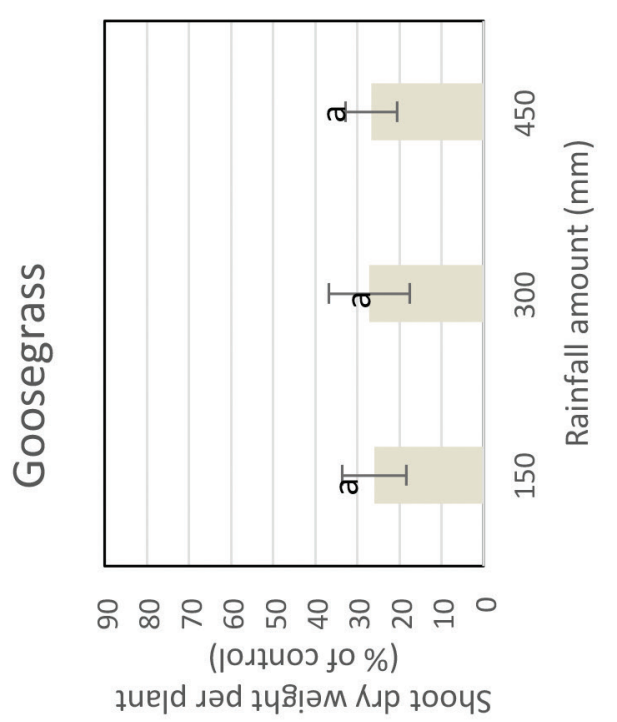

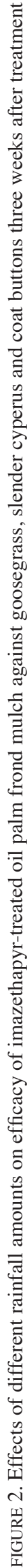


imazethapyr adsorped less under acidic soil condition (Aichele \& Penner 2005). In the present study, the soil pH is 4.3 and this may lead to low desorption of imazethapyr in soil, thus reducing leaching potential of imazethapyr. In addition, the OPF mulches may act as carrier of imazethapyr for slow release of the herbicide (Dilipkumar et al. 2017). The findings of this study clearly showed that rainfall amount was likely to reduce phytotoxic effect of the pretreated OPF for weed control in container nursery because higher weed emergence was apparent under high rainfall.

\section{CONCLUSION}

Imazethapyr in combination with the OPF mulches on inhibition of weed emergence was influenced by the herbicide placement. Both pretreated mulches and imazethapyr applied under the mulches showed comparable inhibition of seedling growth for goosegrass and slender cyperus, but improved inhibition of the weed seedling growth was noted when imazethapyr was applied as a pretreatment on the mulch as compared to that applied above mulch. High inhibition was evident on emergence and growth of coat button without being affected by the imazethapyr placement. Increased rainfall amount could reduce phytotoxic activity of the pretreated mulches against weed seedling emergence except for coat buttons. The pretreated mulches provided great inhibition of weed seedling growth irrespective of any rainfall amounts. The results of this study suggested that efficacy of imazethapyr in combination with OPF residue mulches depends on imazethapyr placement, rainfall amount and weed species. Further research should be conducted by treating OFP mulches with a combination of imazethapyr and other potential pre emergence herbicide against other weed species to provide broad spectrum of weed control in landscapes under field conditions. In addition, experimental period should be extended for three months to assess the duration of inhibitory effect.

\section{ACKNOWLEDGEMENTS}

Financial support was provided by the Ministry of Agriculture and Agro-Based Industry, Malaysia - MARDI.

\section{REFERENCES}

Aichele, T.M. \& Penner, D. 2005. Adsorption, desorption, and degradation of imidazolinones in Soil 1. Weed Technology 19: 154-159.

Ainie, K., Ai, T.W., Kamaruddin, N. \& Beng, Y.C. 2007. Pesticide application in the oil palm plantation. Oil Palm Bulletin 54: 52-67.

Anderson, A.L. 2006. The influence of tillage and landscape on imazethapyr persistence and sorption in soil. MSc dissertation. Manitoba: University of Manitoba (Unpublished).

Broschat, T.K. 2007. Effects of mulch type and fertilizer placement on weed growth and soil $\mathrm{pH}$ and nutrient content. HortTechnology 17: 174-177.
Case, L.T. \& Mathers, H. 2006. Herbicide treated mulches for weed control in ornamentals. Journal of Environmental Horticulture 24: 84-90.

Chalker-Scott, L. 2007. Impact of mulches on landscape plants and the environment-A review. Journal of Environmental Horticulture 25: 239-249.

Chen, Y., Strahan, R.E. \& Bracy, R.P. 2013. Effects of mulching and preemergence herbicide placement on yellow nutsedge control and ornamental plant quality in landscape beds. HortTechnology 23(5): 651-658.

Chuah, T.S. \& Lim, W.K. 2015. Assessment of phytotoxic potential of oil palm leaflet, rachis and frond extracts and powders on goosegrass (Eleusine indica (L.) Geertn.) germination, emergence and seedling growth. Malaysian Applied Biology 44(2): 75-84.

Curran, W.S., Loux, M.M., Liebl, R.A. \& Simmons, F.W. 1992. Photolysis of imidazolinone herbicides in aqueous solution and on soil. Weed Science 40: 143-148.

Dilipkumar, M., Mazira, C.M. \& Chuah, T.S. 2017. The potential use of oil palm frond mulch treated with imazethapyr for weed control in Malaysian coconut plantation. Sains Malaysiana 46(8): 1171-1181.

Faiz, M.A.A. 1999. Effects of herbicides on seed germination and control of Pennisetum polystachion (1.) schult. Journal of Rubber Research 2(2): 120-130.

Gillespie, W.E., Czapar, G.F. \& Hager, A.G. 2011. Pesticide fate in the environment: A guide for field inspectors. Contract Report.p. 10

Jursík, M., Kočárek, M., Hamouzová, K., Soukup, J. \& Venclová, V.2013. Effect of precipitation on the dissipation, efficacy and selectivity of three chloroacetamide herbicides in sunflower. Plant Soil Environment 59(4): 175-182.

Khalid, H., Zin, Z.Z. \& Anderson, J.M. 1999. Effect of oil palm residues management at replanting on soil nutrient dynamics and oil palm growth. Proceeding of the PORIM International Palm Oil Congress. Kuala Lumpur, Malaysia: Malaysian Palm Oil Board. pp. 235-246.

Lanphear, F.O. 1968. Incorporation of Dichlobenil in mulches. Weeds 16: 230-231.

Marble, S.C. 2015. Herbicide and mulch interactions: A review of the literature and implications for the landscape maintenance industry. Weed Technology 29: 341-349.

Martini, G., Pedrinho Junior, A.F.F. \& Durigan, J.C. 2003. Eficácia do herbicida glifosato-potássico submetido à chuva simulada após a aplicação. Bragantia 62(1): 39-45.

Mathers, H. 2003. Novel methods of weed control in containers. HortTechnology 13: 28-31.

Monquero, P.A. \& Silva, A.C. 2007. Efeito do período de chuva no controle de Euphorbia heterophylla e Ipomoea purpurea pelos herbicidas glyphosate e sulfosate. Planta Daninha 25(2): 399-404.

Samtani, J.B., Kling, G.J., Mathers, H. \& Case, L. 2007. Rice hulls, leaf-waste pellets, and pine bark as herbicide carriers for container-grown woody ornamentals. HortTechnology 17: 289-295.

Smith, H.C., Ferrell, J.A., Webster, T.M., Fernandez, J.V., Dittmar, P.J., Munoz, P.R. \& MacDonald, G.E. 2016. Impact of irrigation volume on PRE herbicide activity. Weed Technology 30(3): 793-800.

Somireddy, U.R. 2012. Effect of herbicide-organic mulch combinations on weed control and herbicide persistence. $\mathrm{PhD}$ dissertation. United States: Ohio State University (Unpublished). 
Sondhia, S. 2013. Evaluation of imazethapyr leaching in soil under natural rainfall conditions. Indian Journal of Weed Science 45(1): 58-61.

Thomas, A.F. 1973. Herbicide-impregnated mulches for weed control in container nursery stock. Scientia Horticulturae 1(2): $165-170$

Thomson, W.T. 1993. Agricultural chemicals. Book II Herbicides. Fresno, CA: Thomson Publications.

Vencill, W.K. 2002. Herbicide Handbook. 8th ed. Champaign: Weed Science Society of America. p. 154.

Muhammad Amirul Nordin

School of Food Science and Technology

Universiti Malaysia Terengganu

21030 Kuala Terengganu, Terengganu Darul Iman Malaysia
Dilipkumar Masilamany

Inbred Rice Program

Rice Research Center Malaysian Agricultural Research and Development Institute (MARDI) 13200 Seberang Perai, Kepala Batas, Pulau Pinang

Malaysia

Chuah Tse Seng*

Faculty of Plantation and Agrotechnology

Universiti Teknologi MARA

02600 Arau, Perlis

Malaysia

*Corresponding authors; email: chuahts@perlis.uitm.edu.my

Received: 3 May 2018

Accepted: 15 December 2018 